Volume 5, Issue 3, October 2020, pp. 276-288

DOI: $10.23917 /$ jramathedu.v5i3.10696

p-ISSN: 2503-3697, e-ISSN: 2541-2590

\title{
Improving student's mathematical problem solving skills through Quizizz
}

\author{
Setiyani Setiyani ${ }^{1 *}$, Nur Fitriyani ${ }^{1}$, Laela Sagita ${ }^{2}$ \\ ${ }^{1}$ Department of Mathematics Education, Universitas Swadaya GunungJati, Indonesia \\ 2Department of Mathematics Education, Universitas PGRI Yogyakarta, Indonesia \\ *Corresponding author: setiyanii@fkip-unswagati.ac.id
}

\section{ARTICLE INFO}

Article history:

Received: 14 April 2020

Revised: 10 June 2020

Accepted: 30 June 2020

Published online: 17 July 2020

Published regularly: October 2020

Keywords:

Mathematical problem solving, Quizizz, learning media

\section{ABSTRACT}

The Industrial Revolution 4.0 on Education in Indonesia affects school activities rapidly. Teachers are no longer educated in classrooms only, but they can also utilize technology to conduct distance learning. One interactive application that can be used as a form of question exercise is Quizizz. Therefore, this research aims to: first, examine the effectiveness of students' activities by using Quizizz on mathematical problem-solving skills; second, investigate the differences in the increase in students' ability to solve mathematical problems between the class with and without the Quizizz-aided learning method; third, describe the activities of students who used the Quizizz-aided drill learning method; and fourth, describe the students' responses in using Quizizz. The research was quasi-experiment with a pretest-posttest non-equivalent control group design. The participants in this study are 67 of 10 th students divided into experimental and control classes. Data collection techniques used were tests for students' mathematical problem-solving skills and questionnaires. The instruments were validated using Pearson correlation, while the reliability was tested using Cronbach's Alpha. Then, the N-gain test was used to analyze the data. The results showed that there was an effect on students' learning activities by using Quizizz on their problem-solving skills. Besides, there was a difference in the improvement of problem-solving skills between the class with and without Quizizz-aided. Furthermore, students' activities in three meetings have increased. Moreover, students provided a positive response in learning using Quizizz. Thus, it can be concluded that Quizizz is effective in improving mathematical problem-solving skills.

(C) 2020 Universitas Muhammadiyah Surakarta

\section{Introduction}

The skill of solving mathematical problems is one of the essential mathematical skills which it is need to be mastered by students who study Mathematics (Hendriana et al., 2017). Problem-solving is also a part required to complete Mathematics learning. It means that to enhance creativity, logic, criticism, and systematic thinking, students must master a series of problem-solving skills in Mathematics (NCTM, 2000). Therefore, solving mathematical problems is a significant part of the learning goals that need to be achieved (Surya et al., 2017). 
PISA 2018 results showed that Indonesia's PISA rating dropped compared to the results in 2015. Furthermore, in the mathematics category, Indonesia ranked 73 with an average score of 379 (Tohir, 2019). This condition was strengthened by the author's observations when conducting a preliminary study in one of Dukupuntang State High Schools. Mathematics learning still used traditional ways in which the teacher explained, provided examples of questions and exercises, then ended it by providing assignments. Based on the results of the interview, the Mathematics teacher gave items that referred to printed books from the government and Students' Worksheet from the publisher. These problems did not yet focus on the mathematical problem-solving procedure. Limited time was also an obstacle for the teacher to adjust students' answers overall.

Furthermore, the learning media used was PowerPoint, which has not yet optimized the function of an android smartphone as a learning resource. Students' mathematical problem-solving skills are still far from expectations. Some causes of background mathematical knowledge, in general, are the availability of learning resources, the learning process, the strength of teachers, and national education policy (Siswono et al., $\underline{2017}$ ). Students usually lack the motivation to participate in learning activities actively. Young students often seek to have some fun learning experiences in class, but Mathematics is a subject that students perceive as not having much "fun" (Zhao, 2018). Therefore, the teachers have an essential role in managing students' interaction with learning resources to achieve the desired results (Sugiyanti \& Muhtarom, 2016). Students' involvement in solving mathematical problems can be optimized with the help of instructional media.

Efforts that are alleged to be able to develop mathematical problem-solving skills are using smartphone media as a learning resource. Some free applications that can be utilized include Edmodo, Socrative, Kahoot, Quizizz, Google Classroom, Flubaroo, Edpuzzle, and many others. Game-based learning is one of the advancements in technology (Wang\& Tahir, 2020). One effort to introduce modern technology in the classroom is through gamification, aiming to increase students' satisfaction in mathematics (Bullón et al., 2018). According to Burguillo's research, digital game-based learning can effectively increase students' attention, interest, creativity, and community relations (Burguillo, 2010). Quizizz is a game-based educational app that brings multiplayer activities to classrooms and makes in-class exercises interactive and fun (Zhao, 2018). Unlike other educational apps, Quizizz has game characteristics such as avatars, themes, memes, and music entertainment in the learning process. There are two main modes in Quizizz, namely the instructor mode as the quiz maker, which can be accessed via Quizizz.com, and the player mode, in this case, is the students, which can be accessed via www.Quizizz.com/join (Saleh \& Sulaiman, 2019). This application is also equipped with a timer to answer each question; if a student answers quickly, the student will get more points than students who answer lower (Juniarta et al., 2020). Quizizz also allows students to compete with each other and motivates them to study. Students take the quiz at the same time in class and see their live ranking on the leader board. Although they work on the questions at relatively the same time, it is difficult for students to cheat because the questions and answers are given randomly (Akhtar et al., 2019). Instructors can monitor the process and download the report when the quiz has finished evaluating the students' performance (Çeker \& Özdaml, 2017). The use of this apps in the mathematic classroom helps stimulate students' interest and improve students' engagement.

Several studies related to the effectiveness of using Quizizz have been done. Quizizz effectively increases students' learning activities in accounting classes and has a positive effect on their learning experience (Zhao, 2018). Furthermore, Quizizz is an interactive quiz application that is more effective in increasing students' enthusiasm in learning because it 
replaces the old quiz way that only involves paper and pens (Wibawa, 2019). However, research using Quizizz that focuses on the effectiveness of Quizizz on mathematical problem-solving skills has never been revealed.

Therefore, this study aims to: first, examine the effect of students' activities in solving problems with the quiz-aided drill method on students' mathematical problem-solving skills; second, identify the difference in increasing the ability to solve mathematical problems between students who applied the Quizizz-aided drill learning method and students who did not apply the method; third, find out the students' activities who applied Quizizz-aided drill learning methods; and fourth, describe the students' responses in using Quizizz. This study will contribute to the teachers in improving students' mathematical problem solving abilities using educational apps as a learning media. Besides, Quizizz can also serve as an alternative application for distance learning, especially during the pandemic.

\section{Research Methods}

Quasi-experimental research utilizing a post-test only control group design was employed to check whether there was a cause-effect relationship among the variables, data, and how the data were compared (Creswell \& Clark, 2011). A quantitative approach was used to compare the final grades of students who had different treatments.

The population in this study was all students of 10th grade at one of the state high schools in Dukupuntangin 2019-2020. The research sample was taken using a purposive sampling technique, which consisted of 67 participants. It was grouped into experimental and control classes. High school students were chosen as samples because they have entered the developmental stage of formal operations as a provision for problem-solving. The class could be matched based on the students that had the same background of knowledge. Both classes' normality was needed to do a parametric test aiming to prove that the classes were distributed normally (Pallant, 2010). The experimental class consisted of twenty-five females and eleven males, while the control class consisted of twenty-one females and ten males. The two classes were given different treatments. The experimental class learned using the Quizizz-assisted drill methods while the control class learned by the drill method without the help of Quizizz.

Data collection techniques used were tests to determine the problem-solving skill and questionnaires to find out students' responses in learning using drill methods assisted by Quizizz interactive media. The multiple-choice test used Quizizz media, but the students solve the problem along with a coherent solution. The examples of the problem-solving test are presented in Figure 1.

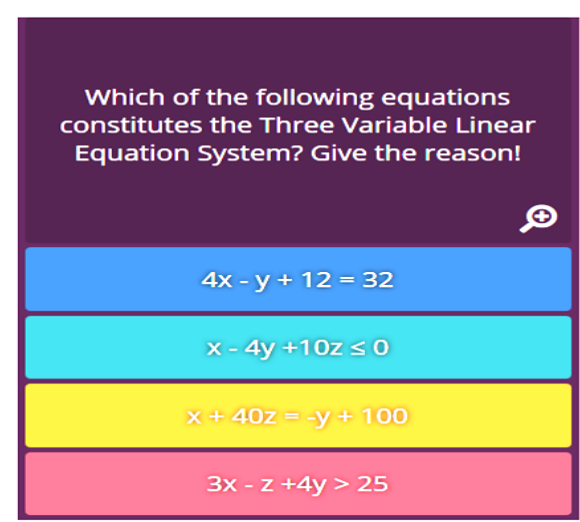

(a)

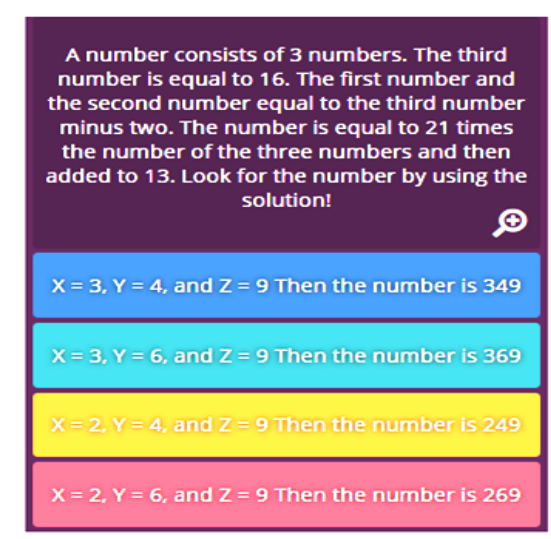

(b)

Figure 1. Problem-solving ability test 
Figure 1 displays two examples of 6 questions concerning problem-solving skills arranged based on the indicators of; identifying data coverage for problem-solving (Figure 1.a), making a mathematical model of everyday situations or problems, and explaining or interpreting the results according to the original question, as well as check the truth of the results or answers (Figure 1.b).

Before using mathematical problem solving, a trial was carried out on the quality of the problem. It was done to find the validity and reliability of each item. The test validity was tested using the Pearson product-moment correlation. An instrument is valid if it can reveal the variables studied precisely or with high validity. The validity test was calculated by SPSS 22 software. The results of the validity test showed that all test items were valid with medium and high levels. Besides, the reliability of the tests measured by using SPSS 22 was also high, with the value of Cronbach's alpha of 0.665 . Therefore, these questions can be used as questions in the current research. A self-learning pre-test in multiple-choice-question format embedded in the Quizizz media was administered to the students to determine their prior knowledge in problem-solving skills. Afterward, the students participated in a written post-test session. At the end of learning, the questionnaire was distributed to measure their response after learning the Quizizz media. Students' responses to the Quizizz questionnaire consisted of 20 statements. Each statement was measured using a Likert scale level with five answers, which are Strongly Agree (SA), Agree (A), Undecided (U), Disagree (D), Strongly Disagree (SD). The sample statements in the questionnaire are listed in Table 1.

Table 1

Questionnaire of students' responses to Quizizz

\begin{tabular}{|c|c|c|c|c|c|c|}
\hline \multirow{2}{*}{ No. } & \multirow{2}{*}{ Statement } & \multicolumn{5}{|c|}{ Alternative Answers } \\
\hline & & SA & A & $\mathrm{U}$ & $\mathrm{D}$ & SD \\
\hline 1. & The display of math quiz on this Quizizz application is interesting. & & & & & \\
\hline 2. & $\begin{array}{l}\text { I think the visual appearance (photos, pictures, etc.) on this Quizizz } \\
\text { quiz apps is exciting. }\end{array}$ & & & & & \\
\hline 3. & I think the use of the Quizizz app increased my learning motivation. & & & & & \\
\hline 4. & $\begin{array}{l}\text { I find it more challenging to understand the quiz questions } \\
\text { presented in the Ouizizz application. }\end{array}$ & & & & & \\
\hline 5. & The Quizizz application is easy to use. & & & & & \\
\hline
\end{tabular}

Post-test data were processed using inferential statistics. Shapiro Wilk test was used for normality tests because the sample was less than 50 , while the homogeneity test used the Levene test. The t-test is used to find out the average difference if the data is normally distributed. Otherwise, the Mann-Whitney test is used. The gain test was used to determine the results of increasing students' mathematical problem-solving skills between before and after learning. The processed gain data was obtained from the difference between the pretest and post-test scores of the experimental class.

Questionnaire data analysis was done on the percentage of student answers. The questionnaire ratings are shown in Table 2.

Table 2.

Criteria for percentage of student responses to Quizizz media

\begin{tabular}{ccc}
\hline No. & Percentage & Criteria \\
\hline 1. & $90-100$ & Excellent \\
2. & $80-89$ & Good \\
3. & $70-79$ & Fair \\
4. & $60-69$ & Poor \\
5. & $<60$ & Very Poor \\
\hline
\end{tabular}


After the data analysis process was carried out, the conclusion was taken of whether or not the use of Quizizz in learning was effective by looking at the criteria: first, the existence or absence of the effect of the activities of students who used Quizizz on their mathematical problem-solving skills; second, the differences of the mathematical problemsolving skills between the experimental and control classes; third, the activities of students who used Quizizz; and fourth, students' response in learning by using Quizizz media.

\section{Result and Discussion}

Teaching and learning activities in Mathematics at one of the state high schools in Dukupuntang were carried out in five meetings. The research data were obtained through evaluation activities, including formative tests conducted for the students in the form of multiple-choice tests and observation of the learning stages using the Quizizz mediaassisted method. The type of test given was multiple choices, but students ought to solve the problem and how to solve them. Students worked on problems with problem-solving steps with limited set time in Quizizz. One of the student's answers after being given a learning treatment using Quizizz is presented in Figure 2.

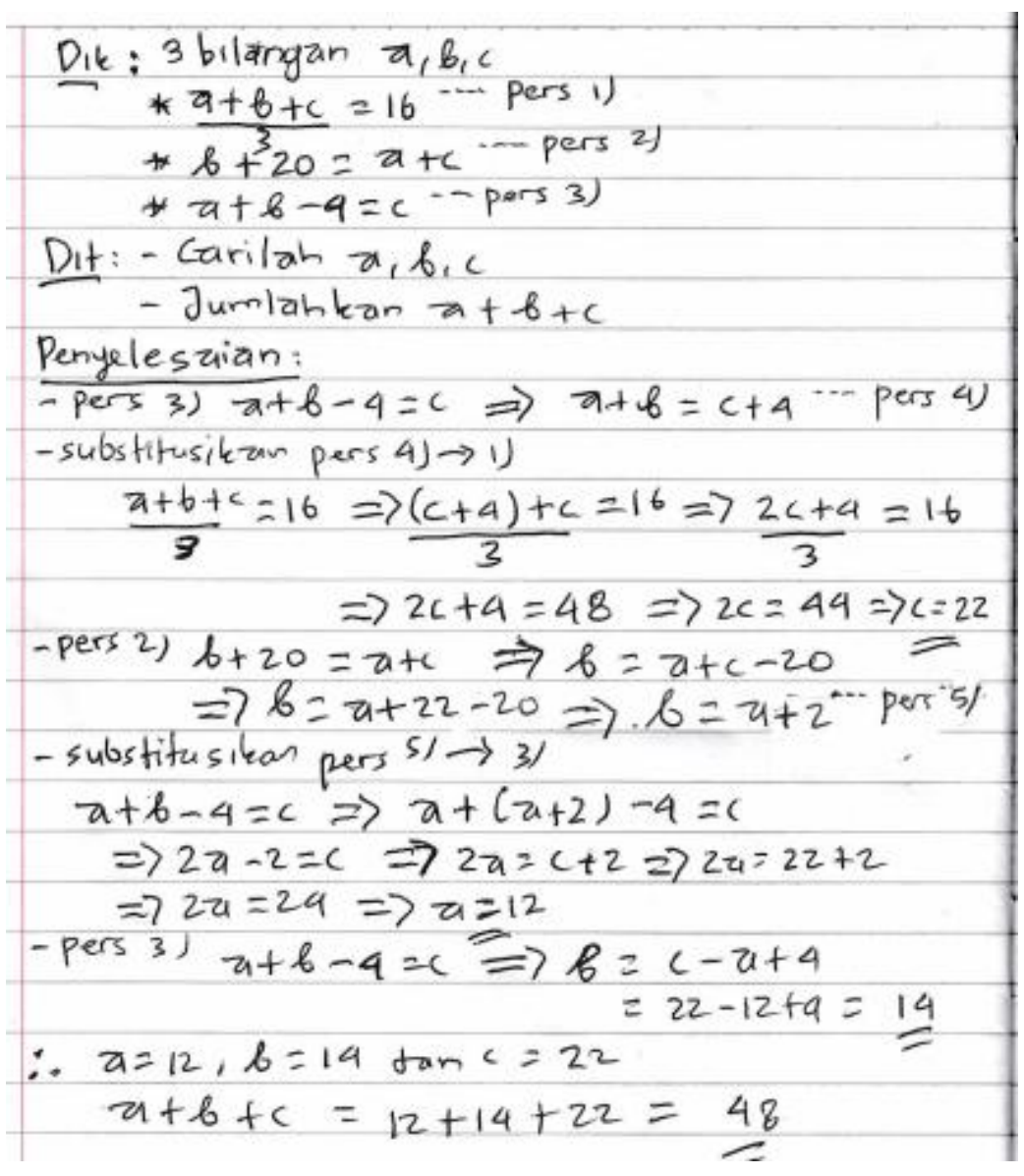

Figure 2. Student's post test answer

Figure 2 displays that student was already able to understand the problem, linked the known elements, chose a solution for the problem and solved the mathematical model. However, students still have not re-examined the correctness of the solution. Based on the results of the interview, students immediately chose the answers on Quizizz without rechecking the answers that have been obtained. 
The first step in using Quizizz for teachers is to register as a teacher by logging in to www.Quizizz.comusingemail or google account they used when registering. After having an account, ask questions for the next learning activities. During the lesson, the teacher open the practice questions on the Quizizz profile and then click "My Quizizz". After that, the teacher needs to double-click on the training material to be carried out. Once ready, the teacher shall select "live game" for direct training. The teacher can also download statistical data about students' performance in the form of an Excel spreadsheet. The first step in using Quizizz for students is to visit www.Quizizz.com. Then, students enter the code that has been shown by the teacher to join the Quizizz platform.

Furthermore, students enter the game rules. They can also see the results of the correct or wrong after the process is complete. The Quizizz display that has been implemented is shown in Figure3.

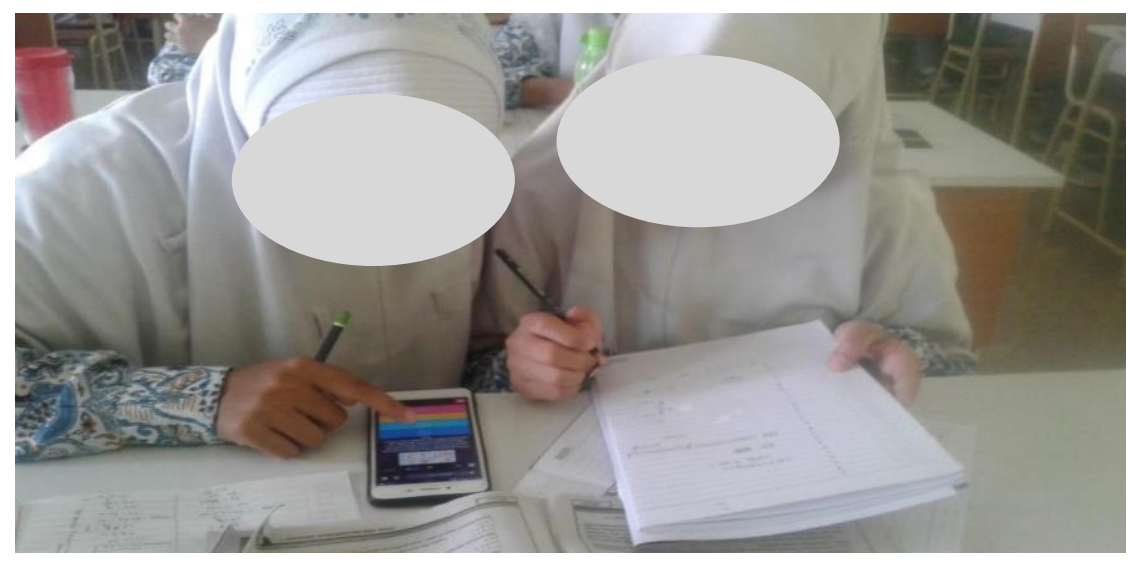

Figure 3. Teaching and learning activities using Quizizz

The implementation of learning, in general, was when the students were asked to observe and learn the material that has been presented on Microsoft power points and games in the form of practical questions on Quizizz media. In face-to-face learning, students were reminded again by asking the material that was previously studied, namely the content of the Linear Equation System in Two Variables (LESTV). By presenting a daily problem related to LESTV to be understood and answered by students, the teachers communicated the learning objectives to be achieved, conveyed the material's scope to be studied, and motivated the students by explaining the importance of learning LESTV material. In the core activities, the teacher organized the students in study groups. Then, students were asked to observe the examples of problems that have been explained and then worked on the examples of problems exercise related to LESTV in groups. Each group consisted of two or three students. After creating the groups, group representatives entered Quizizz media to take part in Quizizz games. The teacher went around, guided, observed, assessed the students' skills, and helped each group that had difficulties in solving problems or challenges in taking Quizizz. The next stage was the examination of group results. The students' work appeared immediately after the estimated time was up. The last step was giving a group reward. Students received positive feedback and reinforcement in oral, written, and prize as an appreciation form of the students' efforts. The teacher and students concluded the material that had been learned. Learners discussed to make a summary of the content that had been submitted. The experimental and control class students worked on the post-test questions in writing in the last meeting. The 
following table presents the descriptive data of the pre-test and post-test results in the experimental class and control class.

Table 3

Descriptive research data results

\begin{tabular}{ccccc}
\hline Statistics & \multicolumn{2}{c}{ Experimental Class } & \multicolumn{2}{c}{ Control Class } \\
& Pre-test & Post-test & Pre-test & Post-test \\
\hline Student $(\mathrm{N})$ & 36 & 36 & 31 & 31 \\
Biggest score & 45 & 90 & 65 & 90 \\
Smallest score & 15 & 35 & 8 & 40 \\
Range of score & 30 & 55 & 57 & 50 \\
Average score & 25.44 & 66.86 & 30.35 & 60.97 \\
Variance & 54.31 & 156.40 & 249.70 & 235.97 \\
Std. Deviation & 7.37 & 12.51 & 15.80 & 15.36 \\
\hline
\end{tabular}

Table 3 shows that the experimental class experienced an average increase of 47.54, while the control class experienced an average increase of 30.62. It means that both classes had a significant increase in the average. Furthermore, the data were analyzed using statistical tests to find the effect of students' activities on mathematical problem-solving skills as well as differences in the skills of the experimental class and the control class.

The Effect of Quizizz Media Assisted Method on Students' Mathematical Problem-Solving Skills

Students' activities using Quizizz on students' mathematical problem-solving skills were determined by conducting an analysis test, a simple linear regression test and determination. The test results are in Table 4.

Table 4

Output of the linear regression

\begin{tabular}{|c|c|c|c|c|c|c|}
\hline \multirow{2}{*}{\multicolumn{2}{|c|}{ Model }} & \multicolumn{2}{|c|}{ Unstandardized Coefficients } & \multirow{2}{*}{$\begin{array}{c}\text { Standardized } \\
\text { Coefficients } \\
\text { Beta } \\
\end{array}$} & \multirow[b]{2}{*}{$t$} & \multirow[b]{2}{*}{ Sig. } \\
\hline & & $\mathrm{B}$ & Std. Error & & & \\
\hline 1 & (Constant) & 35.918 & 5.731 & & 6.267 & .000 \\
\hline & Student's Activity & 3.417 & .610 & .693 & 5.601 & .000 \\
\hline
\end{tabular}

Table 4 shows that the output results show Sig .value of 0.000 ; this value is smaller than $\alpha=$ 0.05 . Hence, it can be concluded that there was a significant effect on students' activities in mathematics learning using Quizizz on the students' mathematical problem-solving skills.

Table 5

\begin{tabular}{|c|c|c|c|c|}
\hline \multicolumn{5}{|c|}{ Coefficient of determination } \\
\hline Model & $\mathrm{R}$ & R Square & Adjusted R Square & $\begin{array}{l}\text { Std. An error of the } \\
\text { Estimate }\end{array}$ \\
\hline 1 & $.725^{\mathrm{a}}$ & .526 & .510 & 7.157 \\
\hline
\end{tabular}

Table 5 shows that R Square was $0.526(0.526 \times 100 \%=52.6 \%)$. It means that the skill to solve mathematical problems can be affected by the variable of the Quizizz mediaassisted method's implementation by $52.6 \%$. In contrast, $47.4 \%$ is explained by other variables besides the variables used in the study.

Students' activities had been increased from the first meeting to the last meeting. Students who were initially unenthusiastic in group learning were eventually enthusiastic. Students also became more active in teaching and learning activities, not ashamed to ask 
questions, and helped each other. It is in line with Saleh and Sulaiman's research, which states that the use of Quizizz makes students more confident, actively involved in class, learning is more student-centered, so it is more effective (Saleh \& Sulaiman, 2019). Another study on similar topics found that participants play Quizizz in class; each student plays their smartphone or laptop; and the teacher must make sure that every one of them has joined the Quizizz by entering the code that has been shared (Mei et al., 2018).

\section{The Difference in Increasing the Mathematical Problems Solving Skills}

Before testing the difference in increasing the skills to solve mathematical problems between the two classes, a normality test was first performed to determine the data distribution. The normality test in this study was used to test the N-Gain data from each group, the experimental class, and the control class to determine whether the data obtained was normally distributed. The normality test used was the Shapiro-Wilk test because the sample used was less than 50 students (Sundayana, 2015).

Table 6

Normality Test

\begin{tabular}{lcccccr}
\hline & \multicolumn{3}{c}{ Kolmogorov-Smirnov $^{\mathrm{a}}$} & \multicolumn{3}{c}{ Shapiro-Wilk } \\
& Statistic & df & Sig. & Statistic & df & Sig. \\
\hline N_gain_Experimental Class & .224 & 31 & .000 & .878 & 31 & .002 \\
N_gain_Control Class & .120 & 31 & $.200^{*}$ & .964 & 31 & .364 \\
\hline *. Lower bound of the true significance. & & & & & \\
a. Lilliefors Significance Correction & & & &
\end{tabular}

Table 6 shows the normality test result showing the Sig. by using Shapiro-Wilk was 0.002 for $\mathrm{N}$-Gain experimental class and 0.364 for the N-Gain control class. It turned out that for the N-Gain experimental class, the Significant/ Sig. value is smaller than the probability value of Sig. or $0.05>0.002$. It means that the data was not normally distributed. As for the N-Gain control class, the Sig. is greater than the probability value of Sig. or $0.05<0.364$, which means the data was normally distributed.

The N-Gain experimental class data was not normally distributed. In contrast, the NGain control class data were normally distributed so that it was continued with nonparametric statistics using the Mann Whitney-U Test. The Mann Whitney-U test aimed to determine the real difference between the average of two populations with the same distribution through two independent samples taken from both populations.

Table 7

The output of Mann Whitney test of N-Gain of experimental and control classes

\begin{tabular}{lr}
\hline & N_GainGab \\
\hline Mann-Whitney U & 339.500 \\
Wilcoxon W & 835.500 \\
Z & -2.751 \\
Asymp. Sig. (2-tailed) & .006 \\
\hline
\end{tabular}

Table 7 shows that the value of Asymp. Sig. (2-tailed) was $0.006<0.05$. It means that, there was a difference in the mathematical problem-solving skills between the experimental class students and the control class students. The results of this study are in line with Albeta, et al. who stated that classes taught by classical learning experience increase in chemistry learning outcomes by 39.5\%, while for classes taught ICT-based tournament learning using Quizizz obtained an increase in chemistry learning outcomes by $75.2 \%$ (Albeta et al., 2020). 


\section{Students' Activities Observation Sheet}

The data on the observation sheet of students' activities shows that in conducting the learning process, researchers conducted exercises by those listed in the lesson plan. They started from the events in the preliminary activities, which included entering the class on time, opening the lesson by greetings, asking for readiness to follow the experience, conveying the material, delivering the objectives, learning the methods that would be used, motivating the students, and exploring the students' background knowledge. Activities in the core activity are explaining the content and giving examples of practical questions in the form of online games on Quizizz media. Afterward, students discussed and solved the problems on Quizizz media.

At the first meeting, the teacher discussed the prerequisite material and the characteristics of the three-variable linear equation system so that students could not be active. However, some students still dared to ask the teacher about what they did not understand yet. Students began to be enthusiastic about the learning process after being introduced to an online game application to practice math problems called Quizizz. However, there were still some students who did not understand how to use the media. Furthermore, in the 3rd meeting, students were already seen to be active in the learning process. They were accustomed to using the interactive media Quizizz and dared to ask questions about anything they had not yet understood. Students' activities in the learning process also determine the effectiveness of the teaching methods and learning resources. The graphs of student activity in the experimental class at the 1st meeting to the 3rd meeting of the experimental class can be seen in Figure 4.

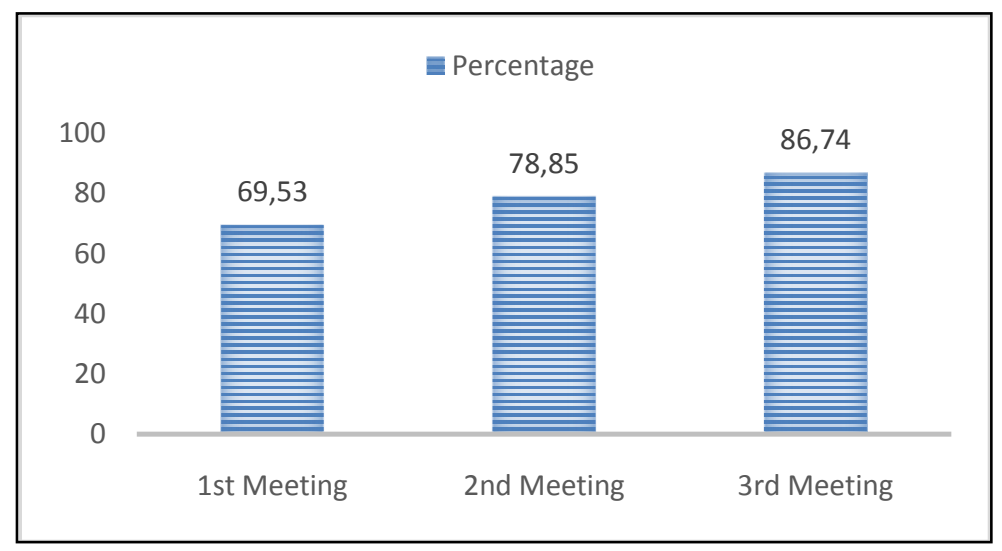

Figure 4. Percentage of the student activity

Figure 3 shows that the use of Quizizz application also allowed students to be actively involved in learning outside the classroom. It can be monitored with the number of Quizizz that can be completed, the number of badges awarded, the number of challenges that were tried, the number of resources downloaded, and the level students have achieved (Stewart \& Chung, 2016). A survey conducted by Permana and Permatawati shows that students preferred to do live Quizizz in class rather than as homework assignments (Permana \& Permatawati, 2020). Therefore, the teacher, as a facilitator, still plays an essential role in learning. 


\section{Students' Responses to Quizizz Interactive Media}

A student response questionnaire was used to assess students' responses after using Quizizz media. The results of the analysis of the questionnaire data responses of students to the Quizizz media were presented in Figure 5.

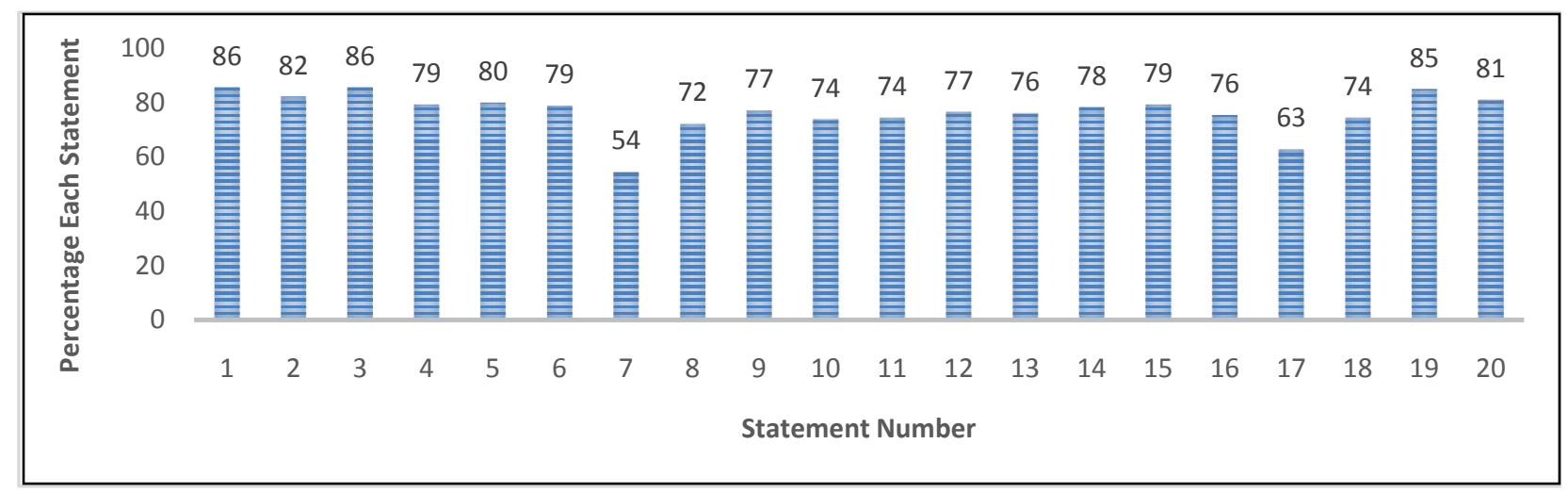

Figure 5. Student responses

Figure 5 shows the results of student responses using questionnaire learning using drill methods assisted by Quizizz interactive media. Almost all students felt the benefits and usefulness of the learning process. Quizizz display, which is interesting, and something new for students, make the learning not dull. These aspects obtained the highest score in the questionnaire assessment of $86 \%$ and the overall statement score is $76.67 \%$ with proper interpretation. The improvement of problem-solving skills in this study is in line with the research results of Sulastri, et al. The application of the LAPS-Talk-Ball learning model integrated on Android-based interactive games can train students' complex problem-solving skills. Based on the results of the calculation of the gain test in the experimental class, the results obtained were0.707 (Sulastri et al., 2019). These results are in line with Meng et al. study that worked on questions using Quizizz applications limited by time. The ranking given during the quiz made students feel satisfied, more focused, competitive, and motivated in solving the questions (Meng et al., 2019). Some disadvantages of using Quizizz include the platform only available in English and online, so an internet connection is required to create and respond to the quiz (Junior, 2020). The use of the Quizizz-aided media drill method is more effective in improving students' learning outcomes than conventional methods. Quizizz is a measurable learning tool that can motivate and engage students with their content (Amornchewin, 2018). However, the results of this study are not in line with the research by Göksün and Gürsoy which the use of the Quizizz application in gamification activities used in research did not have a positive effect on academic achievement and student participation (Göksün \& Gürsoy, 2019).

\section{Conclusion}

There was an effect on students' learning activities using Quizizz on their problemsolving skills. Furthermore, the improvement of problem-solving skills is difference between the classes with and without Quiziz-aided learning methods. In case of the students' activity, it increased significantly in the three meetings conducted. Meanwhile, the students' responses to the use of Quizizz are in good criteria. Hence, the Quizizz media is effectively used in learning to improve mathematical problem-solving skills. Quizizz is very useful as a learning media in dealing with changes from 3.0 industrial revolution, 
where mathematics learning is still dominated hands-on media, to 4.0 era where more emphasize on the use of digital media such as software applications. Therefore, the blended-leaning strategy, which combines face-to-face and online learning, will become a necessity in this era. Further research will investigate the perceptions and challenges of the teachers in applying the Quizziz in learning. Besides, the practicality in using Quizziz as learning apps is also important to discover.

\section{Acknowledgment}

We would like to thanks to Universitas Swadaya GunungJati for providing the research funding. We would also gratitude to SMAN 1 Dukupuntang for being trustworthy partners so that this research can be completed well. Lastly, we do really appreciate to Much. Subali Noto, M.Pd, and Dr. Sri Adi Widodo, M.Pd as the advisor of the manuscript.

\section{Bibliography}

Akhtar, H., \&Hasanati, N. (2019).Game-Based Learning: Teachers'attitude and Intention to Use Quizizzin the Learning Process. 2nd International Conference on Educational Assessment and Policy(ICEAP 2019). https://doi.org/10.26499/iceap.v0i0.202

Albeta, S. W., Nofianti, N., \&ahmandani, S.(2020).PerananTurnamenBerbasisIctDenganAplikasiQuizizzTerhadapPembelajaran Kimia. Jurnal Pendidikan Kimia Universitas Riau, 5(1), 11-15. http://dx.doi.org/10.33578/jpk-unri.v5i1.7778

Amornchewin, R. (2018). The Development of SQL Language Skills in Data Definition and Data Manipulation Languages Using Exercises with Quizizz for Students' Learning Engagement. Indonesian Journal of Informatics Education, 2(2), 85-90. https://doi.org/10.20961/ijie.v2i2.24430

Bullón, J. J., Encinas, A. H., Sánchez, M. J. S., \& Martínez, V. G. (2018). Analysis of student feedback when using gamification tools in Math subjects. In 2018 IEEE Global Engineering Education Conference (EDUCON) (pp. 1818-1823). IEEE. https://doi.org/10.1109/EDUCON.2018.8363455

Burguillo, J. C. (2010). Using game theory and competition-based learning to stimulate student motivation and performance. Computers \& Education, 55(2), pg566-575. https://doi.org/10.1016/i.compedu.2010.02.018

Çeker, E., \&Özdaml, F. (2017). What" Gamification" Is and What It's Not. European Journal of Contemporary Education, 6(2), 221-228. https://doi.org/10.13187/ejced.2017.2.221

Creswell, J.W, and Plano Clark (2011). Designing and Conducting Mix-Method Research (2nd Ed). Thousand Oaks: CA: Sage.

Göksün, D. O., \&Gürsoy, G. (2019). Comparing success and engagement in gamified learning experiences via Kahoot and Quizizz.Computers \& Education, 135, 15-29. https://doi.org/10.1016/i.compedu.2019.02.015

Hendriana, H., Rohaeti, E. E., \&Sumarmo, U. (2017). Hard skills dan soft skills matematiksiswa. Bandung: RefikaAditama.

Juniarta, P. A. K., Dewi, K. S., Mahendrayana, G., \&Swandana, I. W. (2020). The Analysis on the Implementation of Mobile-Assisted Language Learning Strategy Through Quizizz Application to Improve Student's Reading Comprehension at UndikshaSingaraja. In 
3rd International Conference on Innovative Research Across Disciplines (ICIRAD 2019) (pp. 323-327). Atlantis Press. https://dx.doi.org/10.2991/assehr.k.200115.053

Junior, J. B. B. (2020). Assessment for learning with mobile apps: exploring the potential of Quizizz in the educational context. International Journal of Development Research, 10(01), 33366-33371. https://dx.doi.org/10.37118

Mei, S., Ju, S., \& Adam, Z. (2018). Implementing Quizizz as Game Based Learning in the Arabic Classroom. European Journal of Social Science Education and Research, 5(1), 194-198. https://dx.doi.org/10.26417/ejser.v5i1.p194-198

Meng, C. K., Nasir, J. S. B. M., Ming, T. M., \& Choo, K. A. (2019). A Gamified Classroom with Technical and Vocational Education and Training (TVET) Students using Quizizz. International Journal of Education, Islamic Studies and Social Sciences Research, 4 (1).Retrieved From: http://ijeisr.net/Journal/Vol-4-No-1-Isu-02.pdf

NCTM. (2000). Principles and Standards for School Mathematics. Reston. Virginia: National Council of Teachers of Mathematics.

Permana, P., \&Permatawati, I. (2020, March). Using Quizizz as a Formative Assessment Tool in German Classrooms. In 3rd International Conference on Language, Literature, Culture, and Education (ICOLLITE 2019) (pp. 155-159). Atlantis Press. https://dx.doi.org/10.2991/assehr.k.200325.073

Pallant, J (2010). SPSS Survival Manual: A step by step guide to data analysis using SPSS. New York: Allen and Unwin Book Publishers, Australia.

Saleh, S. M., \&Sulaiman, H. (2019). Gamification in T\&L of mathematics: Teacher's willingness in using Quizizz as an additional assessment tool. In AIP Conference Proceedings (Vol. 2184, No. 1, p. 030005). AIP Publishing LLC. https://doi.org/10.1063/1.5136373

Siswono, T. Y. E., Kohar, A. W., \& Hartono, S. (2017). Secondary teachers' mathematicsrelated beliefs and knowledge about mathematical problem-solving. In Journal of Physics: Conference Series (Vol. 812, No. 1, p. 012046). https://doi.org/10.1088/1742-6596/812/1/012046

Sugiyanti, S., \&Muhtarom, M. (2017). Students' Ability and Thinking Profile in Solving Plane Problems by Provision of Scaffolding. JRAMathEdu (Journal of Research and Advances in Mathematics Education), 1(2), 120-130. https://doi.org/10.23917/jramathedu.v1i2.3387

Sulastri, S., Asfar, A. I. T., Asfar, A. I. A., Jamaluddin, J., Ayuningsih, A. N., \&Nurliah, A. (2019). Pengaplikasian Quizizz Pada Pembelajaran Laps-Talk-Ball DalamMelatihKemampuan Complex Problem Solving Siswa. In Seminar Nasional Hasil Penelitian\&PengabdianKepada Masyarakat (SNP2M) (pp. 341-346). Retrieved from http://jurnal.poliupg.ac.id/index.php/snp2m/article/viewFile/1965/1808

Surya, E., \& Putri, F. A. (2017). Improving Mathematical Problem-Solving Ability and SelfConfidence of High School Students through Contextual Learning Model. Journal on Mathematics Education, 8(1), 85-94. http://dx.doi.org/10.22342/jme.8.1.3324.85-94

Stewart-McKoy, M., \& Chung, S. (2016). Back in the game": Using gamification as an engagement tool with Spanish Language Learners at UTech, Jamaica. The Journal of Arts, Science and Technology, 9, 124-144.

Sundayana, R. (2014). Statistika Penelitian Pendidikan. Bandung: Alfabeta.

Tohir, M. (2019). Hasil PISA Indonesia Tahun 2018 Turun Dibanding Tahun 2015. https://doi.org/10.17605/OSF.IO/8Q9VY 
Wang, A. I., \& Tahir, R. (2020). The effect of using Kahoot! for learning-A literature $\begin{array}{llll}\text { review. Computers \& Education, 149, } & 103818 .\end{array}$ https://doi.org/10.1016/i.compedu.2020.103818

Wibawa, R. P., Astuti, R. I., \&Pangestu, B. A. (2019). Smartphone-Based Application "Quizizz" as a Learning Media. Dinamika Pendidikan, 14(2), 244-253. DOI: https://doi.org/10.15294/dp.v14i2.23359

Zhao, F. (2019). Using Quizizz to Integrate Fun Multiplayer Activity in the Accounting Classroom. International Journal of Higher Education, 8(1), 37-43. https://doi.org/10.5430/ijhe.v8n1p37 